\title{
Two new species of gall midges (Diptera, Cecidomyiidae) associated with Protium heptaphyllum (Aubl.) Marchand (Burseraceae) in Brazil
}

\author{
Karine L. Narahara ${ }^{1}$; Valéria Cid Maia ${ }^{2} \&$ Ricardo F. Monteiro ${ }^{1}$
}

\begin{abstract}
${ }^{1}$ Laboratório de Ecologia de Insetos, Departamento de Ecologia, Instituto de Biologia, Universidade Federal do Rio de Janeiro, CCS. Caixa Postal 68020, Ilha do Fundão, 21941-590 Rio de Janeiro-RJ, Brazil. E-mails: knarahara@terra.com.br; monteiro@biologia.ufrj.br ${ }^{2}$ Departamento de Entomologia, Museu Nacional, Universidade Federal do Rio de Janeiro, Quinta da Boa Vista, São Cristovão $20940-049$ Rio de Janeiro-RJ, Brazil.
\end{abstract}

\begin{abstract}
Resumo. Duas espécies novas de cecidomí́deos (Diptera, Cecidomyiidae) associados a Protium heptaphyllum (Aubl.) Marchand (Burseraceae) no Brasil. Duas novas espécies de Cecidomyiidae (Diptera) que formam galhas em Protium heptaphyllum (Burseraceae) são descritas: Dactylodiplosis heptaphylli sp. nov. (Rio de Janeiro) e Lopesia similis sp. nov. (Rio de Janeiro). Algumas informações biológicas e ecológicas são também apresentadas.

Palavras-Chave. Dactylodiplosis; espécies novas; galha; Lopesia; Neotropical; restinga.

Abstract. Two new species of Cecidomyiidae (Diptera) that form galls on Protium heptaphyllum (Burseraceae) are described: Dactylodiplosis heptaphylli sp. nov. (Rio de Janeiro) and Lopesia similis sp. nov. (Rio de Janeiro). Some biological and ecological informations are also provided.
\end{abstract}

KEYwords. Dactylodiplosis; gall; Lopesia; Neotropical; new species; restinga.

Cecidomyiidae (Diptera) are the principal gall inducers in the world (GAGNÉ 1994), but studies about these midges are scarce for the Neotropical Region. The present work is part of an attempt to bring more information about galling insects of the Atlantic Forest, with special focus on the restinga. Several species have been described from this sandy coastal plain mainly in the state of Rio de Janeiro.

Burseraceae is a pantropical family and in the Parque Nacional da Restinga de Jurubatiba, in Rio de Janeiro state, where our research is in progress, the family is represented by three species of Protium: P. brasiliense (Spreng.) Engl., $P$. heptaphyllum and P. icicariba (DC.) Marchand (Pereira \& ARAúJo 2000). Protium heptaphyllum is the most widely distributed species of this family in Brazil, occurring from the east coast to the north of the country.

In a work on gall midges of restingas, MAIA (2001) reported the occurrence of eight types of galls associated with Protium: two on P. brasiliense; two on P. heptaphyllum; and four on $P$. icicariba. In a recent work (MAIA et al. 2002), two new species of Cecidomyiidae were described for P. icicariba: Dactylodiplosis icicaribae Maia, 2002 and Lopesia simplex Maia, 2002. The genus Lopesia Rübsaamen, 1908 (Diptera: Cecidomyiidae) is the only of the tribe Lopesiini that is not restrict to the neotropics. At least 13 species are known: three from Africa, one from North America and nine from Brazil. Dactylodiplosis Rübsaamen, 1916 (Diptera: Cecidomyiidae) is known from two species from Brazil (GAGNÉ 2004).

Two new species of Cecidomyiidae are herein described found in Protium heptaphyllum, and information about their biology and ecology is provided.

\section{MATERIAL AND METHODS}

The field work was done in the Parque Nacional da Restinga de Jurubatiba (22 00-22 23' S, 41 15'-41 45' W), during May, June, September, October and December of 2002, and February, March, May and June of 2003. The leaves attacked by the gallers were collected and accommodated in plastic bags in the field. In the laboratory, the leaflets were separated by the type of the galls to obtain the specimens. For a month the galls were maintained for rearing of adults, and after that, part of the material was dissected to obtain immatures. The specimens were first preserved in $70 \%$ alcohol. The diameter of the galls were measured $(\mathrm{N}=50)$, and galls per leaf and leaflet were counted.

The cecidomyiids were mounted on slides following the technique in GaGNÉ (1994). The genera were identified based on the key in GAGNÉ (1994). All specimens are deposited in the Diptera collection of MNRJ (Museu Nacional, Universidade Federal do Rio de Janeiro).

The field and the laboratory work was done by Karine L. Narahara and Ricardo F. Monteiro and the taxonomic descriptions were made by Valéria C. Maia.

\section{Dactylodiplosis heptaphylli Maia, sp. nov.} (Figs. 1-18)

Adult. Body length: $2.7-3.0 \mathrm{~mm}$ in male $(\mathrm{N}=2) ; 2.5-3.0 \mathrm{~mm}$ in female $(\mathrm{N}=4)$. Head (Fig. 1): occipital process present and bearing 2 setae. Eye facets hexagonal. First two flagellomeres connate; male flagellomeres binodal and tricircumfilar, 
circumfilar loops equal in length (Fig. 2); female flagellomeres cylindrical with circumfila as in Fig. 3; necks setulose; twelfth flagellomere with apical process. Frontoclypeus with 6-8 long setae. Labrum triangular, long-attenuate, with three pairs of ventral sensory setae and lateral setulae. Hypopharynx of similar shape as labrum, with lateral setulae. Labella each hemispherical, with few lateral and two or three mesal sensory setae. Palpus with four cylindrical segments with setulae and setae.; length of segment 1, $0.03 \mathrm{~mm}$; segment 2, 0.06-0.07 mm; segment $3,0.06-0.07 \mathrm{~mm}$; segment 4, 0.09-1.0 mm. Thorax: wing length from arculus to apex: $2.1 \mathrm{~mm}$ in male $(\mathrm{N}=2) ; 2.4-2.65 \mathrm{~mm}$ in female ( $N=4)$. Venation (Fig. 4): Rs situated slightly beyond midlength of R1, partially as strong as R1, weaker anteriorly; $\mathrm{R} 5$ bent at juncture with $\mathrm{C}$; Ms fold present; $\mathrm{Cu}$ forked; $\mathrm{CuP}$ present. Anepisternum with several setae. Anepimeron with vertical row of 10 setae. Legs: tarsal claws strongly bent near basal third and with one tooth; empodia short (Fig. 5). Male abdomen (Fig. 6): tergites 1-7 rectangular, entirely sclerotized, with single, complete row of setae at distal margin, some lateral setae, irregular row of setae mesally, one pair of basal trichoid sensilla, and elsewhere with scattered scales; tergite 8 bandlike, sclerotized, with only one pair of basal trichoid sensilla as vestiture. Sternites 2-7 rectangular with a row of setae at distal margin, some lateralsetae and irregular rows of setae mesally, one pair of basal trichoid sensilla and elsewhere with scattered scales. Sternite 8 with scattered setae, basal pair of trichoid sensilla and scales elsewhere.

Male terminalia (Fig. 7) gonocoxites with narrow and long mesobasal lobes; gonostylus slightly widest near basis; cercus with lobes ovoid and setose; hypoproct simple, setose and rounded at apex; cerci and hypoproct subequal in length; aedeagus conspicuously longer than hypoproct, elongate with pointet apex. Female abdomen (Fig. 8): tergites 1-6 as in male; tergite 7 incompletely sclerotized at distal margin; tergite 8 as in male. Sternites 2-6 rectangular with an irregular row of setae at distal margin, irregular rows of setae mesally, one pair of trichoid sensilla and elsewhere with scattered scales. Sternite 7 with scattered setae at distal half, one pair of trichoid sensilla and scales elsewhere. Sternite 8 ovoid and setose (Fig. 9). Ovipositor barely protrusible, female cerci not fused, ovoid and setose; two setae longer than the others (Figs. 10).

Pupa. Body length: 2.3-2.7 mm (N=4). Cephalic region (Fig. 11) with antennal horn well developed, pointed at apex (length: 0.09-0.14 mm, $\mathrm{N}=4$ ); upper cephalic margin thickened laterally. Facila papillae not visible; cephalic setae (Fig. 12) 0.04-0.05 $\mathrm{mm}$ in length $(\mathrm{N}=2)$. Thorax: prothoracic spiracle setiform 0.13 $0.14 \mathrm{~mm}$ in length $(\mathrm{N}=2)$ (Fig. 13). Abdominal segments 2-8 without conspicuous spines; covered with diminutive spicules.

Larva. Body Length: $2.1 \mathrm{~mm}(\mathrm{~N}=1)$. Colour: yellow. Integument rough. Spatula (Fig. 14) length: $0.26 \mathrm{~mm}(\mathrm{~N}=1)$, one-toothed, stalk well developed; full complement of lateral papillae; sternal and ventral papillae asetose. Terminal segment with three pairs of setose papillae (Fig. 15).

Gall. Ovoid leaf gall, green, one-chambered, with apical depression, with average diameter of $0,26 \mathrm{~mm}(\mathrm{SD}=0,044$ $\mathrm{N}=50$ ) - Figs. 16-18. The galls are found mainly on the lower surface of the leaves. One to 43 galls per leaf (average $=6,6$; $\mathrm{SD}=8,23 ; \mathrm{N}=50$ ), and from 1 to 19 galls per leaflet (average $=$ 2,$5 ; \mathrm{SD}=2,67 ; \mathrm{N}=132$ ) were counted. The larvae chamber is spheroid and the larva is solitary. Pupation takes place in the gall and the pupa emerges from an operculum in the middle of the structure. Galls can be found throughout the year.

Holotype: male on Protium heptaphyllum: BRAZIL, Parque Nacional da Restinga de Jurubatiba, Lagoa de Carapebus, Estado do Rio de Janeiro, 06.V.2002, K. L. Narahara col. Paratypes: same locality, date and collector: 3 males; 4 females; 5 pupal exuviae and 1 larva.

Distribution. Brazil: Rio de Janeiro.

Remarks. With the addition of the new species, Dactylodiplosis includes three species: D. heisteriae Rübsaamen, 1916; D. icicaribae and D. heptaphylli. The first is associated with Olacaceae, the others with Burseraceae. $D$. heptaphylli differs from the other species mainly in the width of the mesobasal lobes of gonocoxites (conspicuously narrower in the $D$. heptaphylli); in the shape of the spatula (two-toothed in D. icicaribae, one-toothed in D. heisteriae and in D. heptaphylli, but truncate at apex in D. heisteriae and pointed at the apex in $D$. heptaphylli). D. heptaphylli also differs from $D$. icicaribae in having three pairs of terminal papillae instead of four pairs in D. icicaribae.

Etymology. The name heptaphylli is a noun in apposition and refers to the plant species.

\section{Lopesia similis Maia, sp. nov.} (Figs. 19-34)

Adult. Body length: $2.5-2.7 \mathrm{~mm}$ in male $(\mathrm{N}=4) ; 2.9-3.4 \mathrm{~mm}$ in female $(\mathrm{N}=4)$. Head (Fig. 19): occipital process present and bearing five setae. Eye facets circular. First two flagellomeres connate; male flagellomeres binodal and tricircumfilar, first and third circunfila with loops irregular in length, second circunfila bandlike (Fig. 20); female flagellomeres cylindrical with circumfila as in Fig.21; necks setulose ; twelfth flagellomere with apical process. Frontoclypeus with 6-10 long setae. Labrum triangular, long-attenuate, with three pairs of ventral sensory setae and lateral setulae. Hypopharynx of similarshape as labrum with lateral setulae. Labella each elongate-convex, with few lateral and two mesal sensory setae. Palpus: first segment ovoid with about $0.03 \mathrm{~mm}$ in length and $0.025 \mathrm{~mm}$ in width); second segment the longest one about 4.2-4.5 times as long as wide (length: $0.065-0.085 \mathrm{~mm}$ ); third segment about 4.2-4.3 times as long as wide (length: 0.055-0.065 mm); fourth segment about 3.2-4.75 times as long as wide (length: 0.060$0.070 \mathrm{~mm}$ ), all with setulae and setae. Thorax: venation as in figure 22; wing length from arculus to apex: 1.9-2.1 mm in male $(\mathrm{N}=3) ; 2.30-2.65 \mathrm{~mm}$ in female $(\mathrm{N}=4)$. Anepisternum with a few scales near middle. Anepimeron with vertical row of 9-12 setae. Legs: Tarsal claws bent near basal third and toothed; empodia not reaching beyond bend in claws (Fig. 23).

Male abdomen (Fig. 24): tergites 1-6 rectangular with single, 

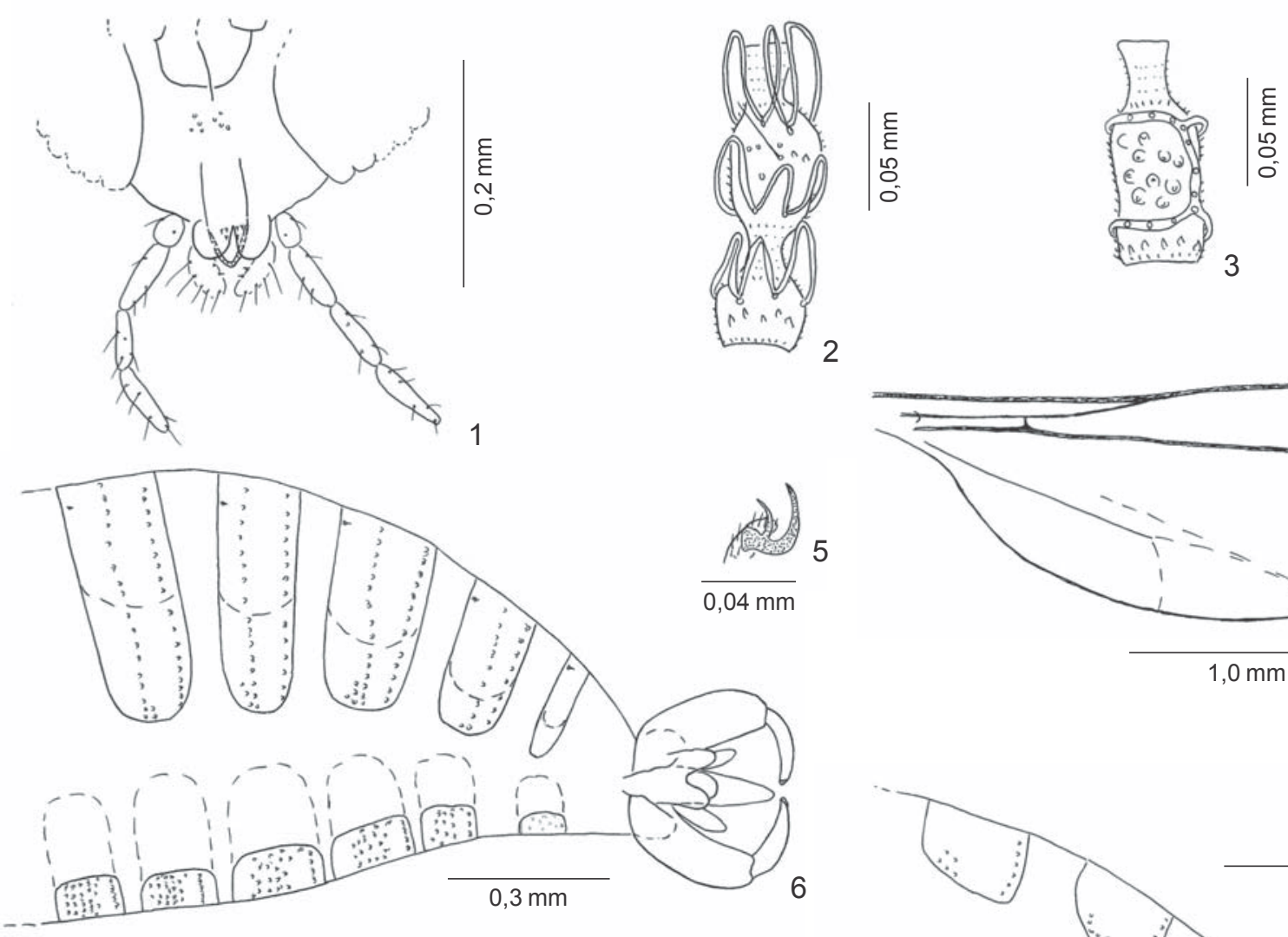

2
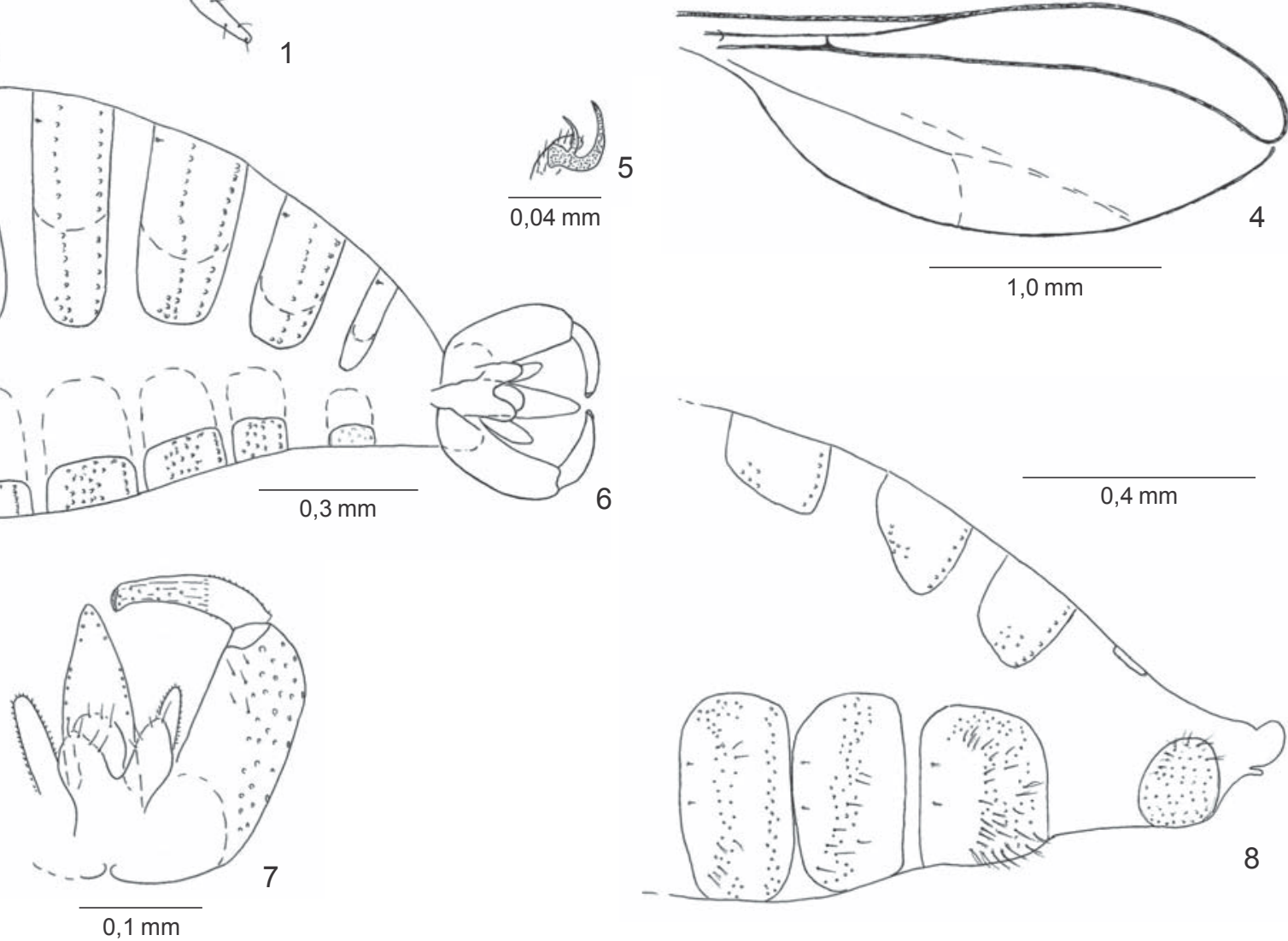

Figs. 1-8. 1-5, Dactylodiplosis heptaphylli sp. nov. Adult: 1, female, mouth parts, frontal view; 2, male flagellomere V; 3, female flagellomere V; 4, female, wing; 5, female, hindleg, empodium and claw, lateral view. 6-8. Adult abdomen: 6, male abdomen, third segment to end, lateral view, excepting male terminalia (dorsal view); 7, female abdomen, fifth segment to end, dorsolateral view; 8, female abdomen, fifth segment to end, ventrolateral view.

complete row of caudal setae, several lateral setae, one pair of basal trichoid sensilla, and elsewhere with scattered scales; tergite 7 not sclerotized in the middle of posterior margin, almost bare with some lateral setae, some scales and a pair of basal trichoid sensilla present. Tergite 8 sclerotized, band-like with only a pair of trichoid sensilla as vestiture. Sternites 2-8 rectangular and setose, setae present only mesally and caudally and a pair of basal trichoid sensilla present; anterior $1 / 2$ of sternite 8 with no setae; basal pair of trichoid sensilla present. Male terminalia (Fig. 25): gonocoxites splayed, gonostylus elongate, narrow and discretely bent, cercus with lobes cylindrical-elongate, cercus and hypoproct similar in width; aedeagus triangular conspicuously longer than hypoproct. Female abdomen (Fig. 26): tergites 1-8 as tergites 1-6 in male. Sternites 2-8 rectangular with setae mesally and caudally, scales elsewhere. Sternite 9 with scattered setae. Ovipositor barely protrusible, female cerci not fused, elongateovoid and setose (Figs. 27).

Pupa. Body length: 2.5-3.0 mm (N=4). Cephalic region (Fig. 28) with antennal horn triangular (length: $0.025-0.03 \mathrm{~mm}$ ); antennal base with a small denticle; upper cephalic margin thickened laterally. Full complement of cephalic, lower and lateral papillae; cephalic setae $0.08-0.09 \mathrm{~mm}$ in length $(\mathrm{N}=4)$. 


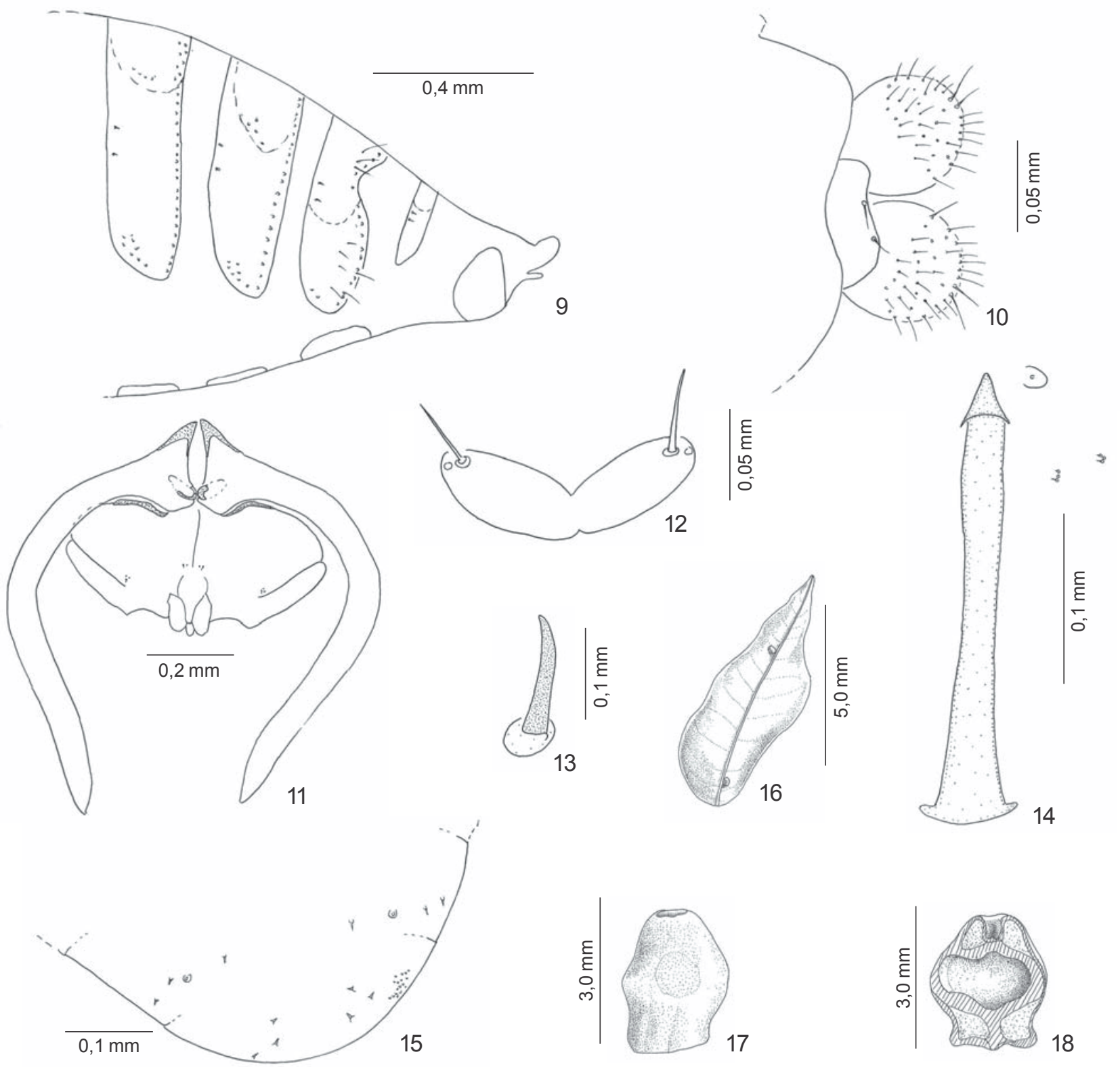

Figs. 9-18. 9-13, Dactylodiplosis heptaphylli sp. nov. Adult and Pupa: 9, male terminalia, dorsal view; 10, female, postabdomen, ventral view; 11, pupa, cephalic region, ventral view; 12, pupa, cephalic setae and asetose papillae; 13, pupa, prothoracic spiracle. 14-18. Larva and gall: 14, larva, spatula and associated papillae, ventral view; 15, larva, terminal segments, dorsal view; 16, gall, general aspect; 17, gall, lateral view showing the initial operculum; 18, gall, internal chamber.

Thorax: prothoracic spiracle 0.28-0.29 mm in length $(\mathrm{N}=4)$ (Fig. 29). Wing sheath reaching basal 2 of abdominal segment 3 ; fore leg sheath reaching basal third of abdominal segment 6 ; mid leg sheath reaching half of segment 6 and hind leg sheath reaching distal margin of segment 6 . Abdominal segments 2-8 without conspicuous spines; covered with diminuve spicules.

Larva. Body length: $2.6 \mathrm{~mm}(\mathrm{~N}=1)$, Colour: white. Spatula 2-toothed (length: 0.23-0.25 mm; $\mathrm{n}=2$ ); full complement of lateral papillae (Fig. 30). Terminal segment with four pairs of setose papillae (Fig. 31).
Gall. This cecidomyiid induces a more simple structure than the previous one, a green rolled leaf margin gall one-chambered -Figs 32-34. The galls have an average length of 1,54 mm (SD $=0,30-\mathrm{N}=50)$, and can be found through the entire year. We found from 1 up to 43 galls per leaf (average $=3,74 ; \mathrm{SD}=2,62$; $\mathrm{N}=50$ ), and from 1 to 19 galls per leaflet (average $=1,5 ; \mathrm{SD}=$ $0,82 ; \mathrm{N}=125)$. The morphology of the internal chamber accompanies the external one, and the gallers are solitary. The larva pupates inside the galls, and the adults emerge from the operculum located in the middle. 

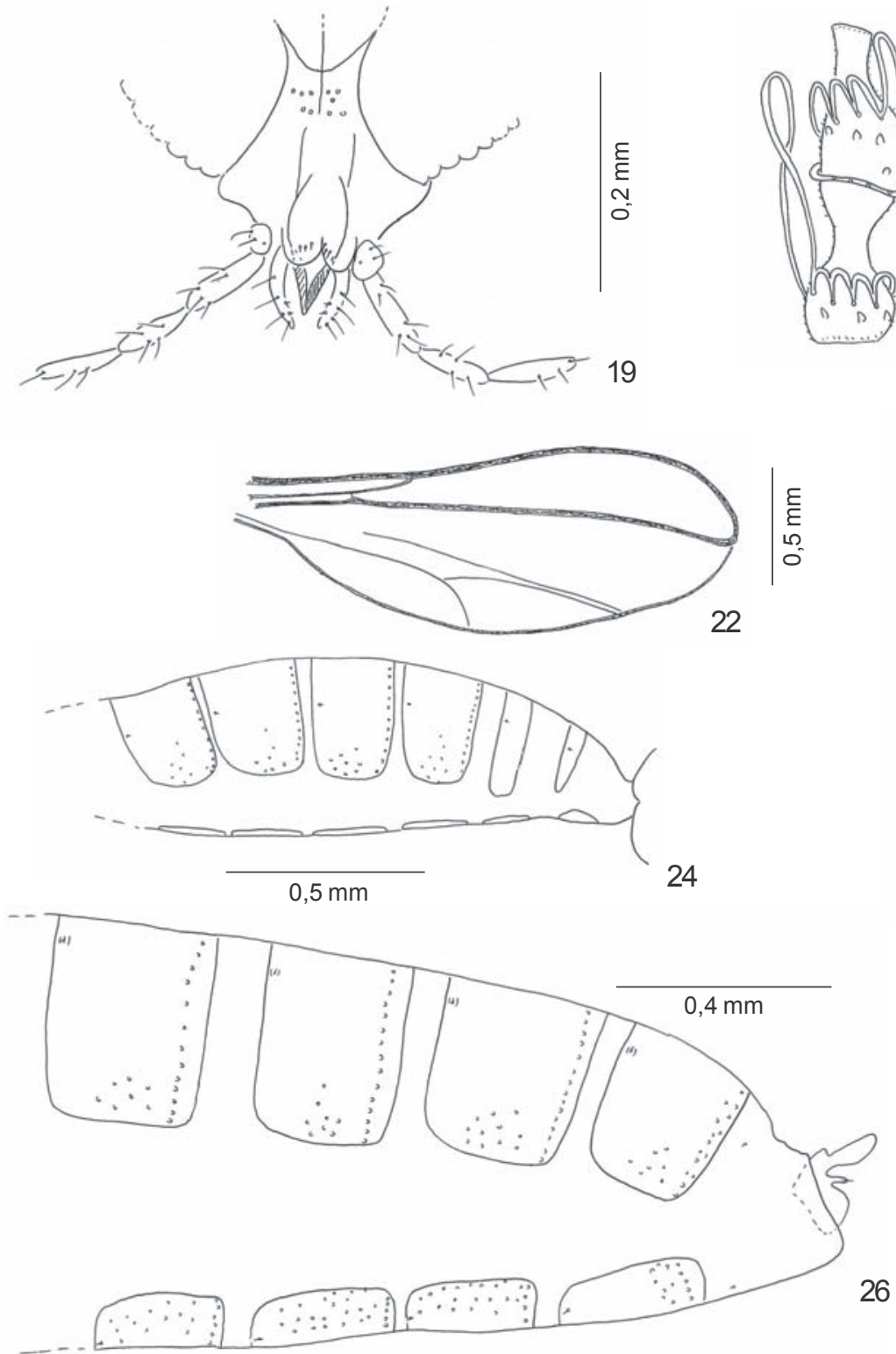

26

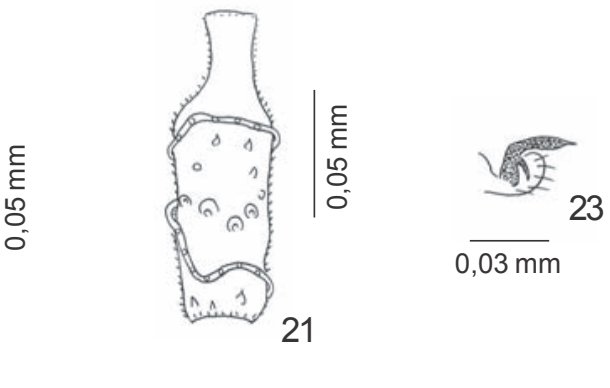

20

Figs. 19-27. 19-23, Lopesia similis sp. nov. Adult: 19, female, mouth parts, frontal view; 20, male flagellomere V; 21, female flagellomere V; 22, male, wing; 23, male, foreleg, empodium and claw, lateral view. 24-27. Adult abdomen. 24, male abdomen, third segment to end, dorsolateral view; 25, female abdomen, fifth segment to end, dorsolateral view; 26, male terminalia, dorsal view; 27, female postabdomen, lateral view.

Holotype: male on Protium heptaphyllum: BRAZIL, Parque Nacional da Restinga de Jurubatiba, Lagoa de Carapebus, State of Rio de Janeiro, 06.V.2002, K. L. Narahara col. Paratypes: same locality, date and collector: 3 males; 4 females; 5 pupal exuviae and 1 larva.

Distribution. Brazil: Rio de Janeiro.

Remarks. This is the second described species of Lopesia after L. simplex associated with Protium (Burseraceae). Both species induce the same kind of gall, leaf marginal roll, but the former is associated with $P$. heptaphyllum and the latter with P. icicariba. The larvae, pupae and adults of both species are similar in many aspects. The shape of the spatula and the complement of lateral papillae are the same, but the terminal segment differs in having conspicuous lobes in L. simplex and no lobes in L. similis and the larval integument of $L$. simplex is rough and that of $L$. similis is spiny. The pupa of both species have the same complement of facial papillae, but differ in the shape of the antennal horn, which is more acuminate apically in L. similis. In addition, the adults of $L$. similis have wider tarsal claws and slender aedeagus, the second segment of the palpus of L. similis is the longest one, while in $L$. simplex the longest palpal segment is the fourth. The male abdominal tergite 7 is incompletely sclerotized in $L$. similis while in $L$. simplex it is entirely sclerotized; the male tergite 8 is entire and bandlike in L. similis and divided into two plates in L. simplex. 

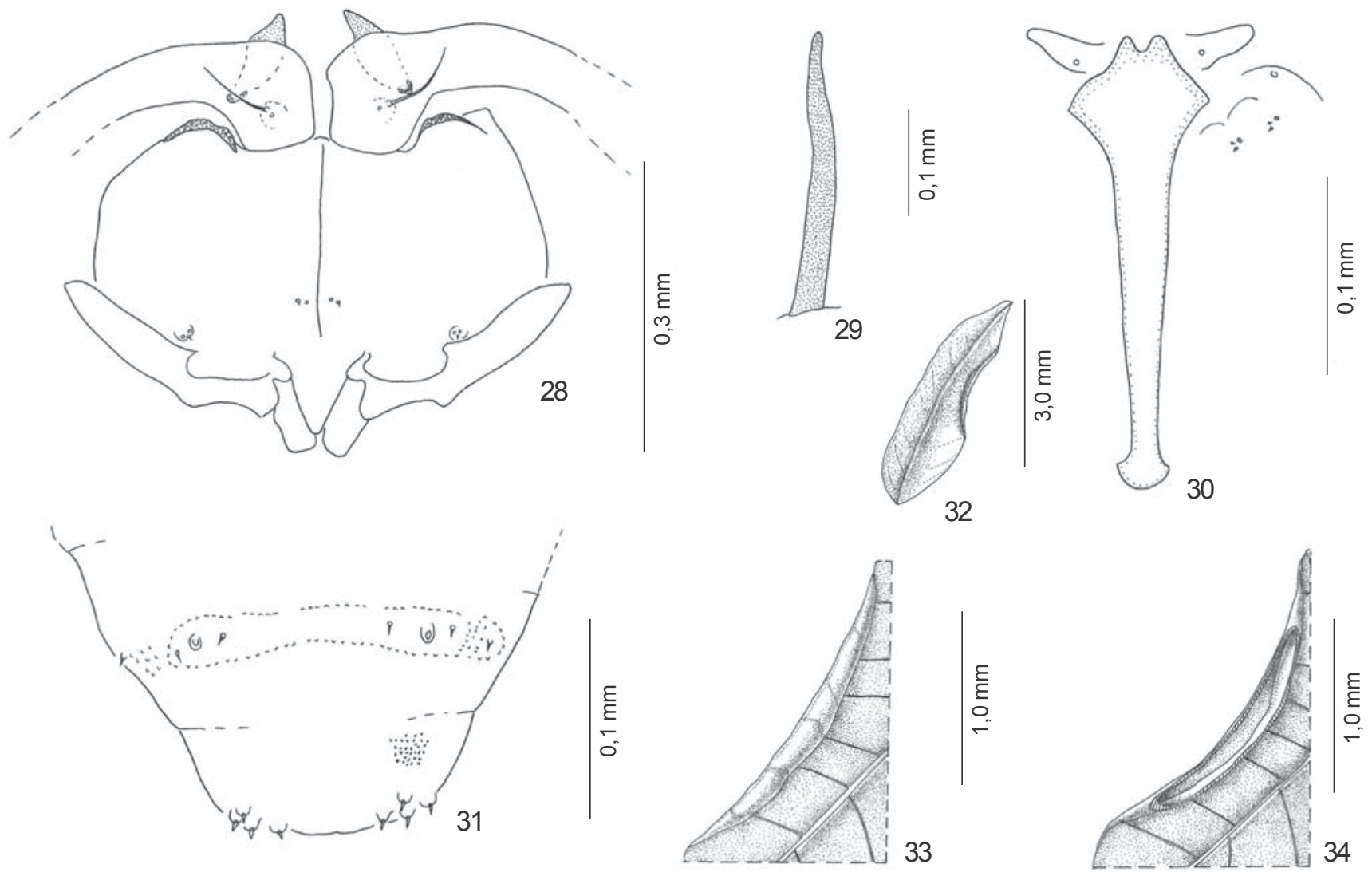

Figs. 28-34. Lopesia similis sp. nov. Pupa, larva and gall: 28, pupa, cephalic region, ventral view; 29, pupa, prothoracic spiracle; 30, larva, spatula and associated papillae, ventral view; 31, larva, terminal segments, dorsal view; 32, gall, general aspect; 33, gall, proximate view; 34, gall, internal chamber.

\section{REFERENCES}

Acknowledgments. We are grateful to PELD/CNPq (Programa de pesquisas Ecológicas de Longa Duração/Conselho Nacional de Desenvolvimento Científico e Tecnológico) (KLN, RFM) and FAPERJ (Fundação de Amparo à Pesquisa do Estado do Rio de Janeiro) (VCM) for the financial support; Universidade Federal do Rio de Janeiro/CNPq (KLN) and CNPq (RFM) for the scolarship support, IBAMA (Instituto Brasileiro de Meio Ambiente e Recursos Naturais Renovávis) for the license to research in Parque Nacional da Restinga de Jurubatiba and Paulo Ormindo (Instituto de Pesquisas Jardim Botânico do Rio de Janeiro) for drawings of the gall structures. Thanks are also due to the referees, who reviewed and improved the manuscript.
Gagné, R. J. 1994. The Gall Midges of the Neotropical Region. Ithaca, Comstock Cornell University Press, $352 \mathrm{p}$.

GAGNÉ, R. J. 2004. A Catalog of the Cecidomyiidae (Diptera) of the World. Memoirs of the Entomological Society of Washington, No. 25. Washington, D. C., The Entomological Society of Washington, $408 \mathrm{p}$.

MaIA, V. C. 2001. The gall midges (Diptera:Cecidomyiidae) from three restingas of Rio de Janeiro State, Brazil. Revista Brasileira de Zoologia 18(2): 583-629.

Maia, V. C.; R. F. Monteiro \& K. L. Narahara 2002. Two new species of gall midges (Diptera, Cecidomyiidae) associated with Protium icicariba (Burseraceae) in Brasil. Studia Dipterologica 9: 171178.

Pereira, O. J. \& D. S. D. Araújo 2000. Análise Florística das Restingas dos Estados do Espírito Santo e Rio de Janeiro, p. 25 - 63. In: F. A. Esteves \& L. D. Lacerda (eds.). Ecologia de Restingas e Lagoas Costeiras. Macaé, NUPEM/UFRJ, 394 p. 